\title{
Post Renal Transplant Infections: A Six Month Follow-Up Study from a Kidney Transplant Institute of North India
}

\author{
Dr. Mohd Ashraf Bhat ${ }^{1}$, Dr. Jawher UI Islam ${ }^{2}$, Dr. Wani Firdous Dawood ${ }^{3}$, Dr. Peerzada Khibrat ${ }^{4}$, \\ Dr. Aamir Shafi ${ }^{5}$ \\ ${ }^{1}$ Department of Nephrology, Sheri Kashmir Institute of Medical Science, Srinagar (Jammu and Kashmir) India. \\ ${ }^{2,3,4,5}$ Department of General Medicine, Sheri Kashmir Institute of Medical Science, Bemina Srinagar (Jammu and Kashmir) India.
}

\begin{abstract}
Transplantation returns the majority of patients to an improved life-style and an improved life expectancy, as compared to patients on dialysis. Infections are the most prevalent cause of morbidity and mortality in kidney transplant recipients, with more than $80 \%$ suffering at least one episode of infection in the first year. The method of data collection in this study was prospective hospital record analysis, all renal transplant recipients were screened pre operatively for the presence of any overt or occult infection. The predominant age group undergoing renal transplantation was between $18-29 \mathrm{yrs}$. Urinary tract infections were the highest and commonest infections observed. The microorganisms involved in the infections were Bacteria (36.4\%), Viruses (7.6\%), Fungi (3.7\%) and Parasites (5.5\%). In Urinary tract infection, E. coli followed by Klebsiella pneumoniae were the predominant bacterial isolates. Candida albicans were the commonest fungi isolated. Among the Gastrointestinal tract infections, Cryptosporodium was the commonest Protozoal isolate. Cryptococcus neoformans was isolated in two cases of meningitis. In this study the organisms causing infection during the immediate operative period have been categorized, which will give the treating physician a reasonable idea to suspect the system and cause of infection during the particular post renal transplant period. This study has focused to evaluate the spectrum of infectious complications in post renal recipients in first 6 months of follow up and evaluate the most common type of infection.
\end{abstract}

KEYWORDS: Immunosuppression, Renal Transplant Infections, UTI.

\section{INTRODUCTION}

Kidney transplantation offers a healthier life over hemodialysis in patients with end-stage renal disease (ESRD). The survival following transplantation is determined by various factors, including pretransplant co-morbidities, graft type, and degree of immunosuppression (Arend et al., 1997). The new developed immunosuppressive drugs has lead to the reduction in mortality of renal transplant recipients (RTRs). Nevertheless, potent immunosuppression poses an extra risk of infectious disorders in the transplant recipients. One quarter of RTR develop a serious infection in the post-transplant period that causes allograft dysfunction (Ram et al., 2005). Bacterial infections are very frequent as compared to the viral infections in RTR. Nearly $13 \%$ of all patients transplanted between 1996 and 2000 in the US needed hospitalization for bacterial infections in the first 3 years compared to 6\% for viral infections (Dharnidharka et al., 2007).

In the period from one to six months after transplantation, infections with immunomodulating viruses, particularly cytomegalovirus, are most important. Cytomegalovirus accounts for two-thirds of febrile episodes during this period. In addition to the clinical syndromes induced by these viruses, their immunomodulating properties predispose to opportunistic infections with such organisms as Pneumocystis carinii, Listeria monocytogenes, and Aspergillus fumigates (Pava, 1993; Fishman, 1995; Hadley and Karchmer, 1995; vanDenberg et al., 1996). Other infections generally occurring during this period include hepatitis, Herpes zoster, Herpes simplex, Mycobacterium tuberculosis, and Epstein-Barr virus (EBV), which can be complicated by the development of lymphoproliferative disorders. Recurrence or relapse of urinary tract infections can also occur (Fishman and Rubin, 1998). Most infections occur early in the post-transplantation course with about two-thirds of renal transplant recipients (RTR) experiencing an infectious-related complication in the first year after transplantation (Maraha et al., 2001). Approximately $70 \%$ of severe bacterial, fungal and viral infections occur within 3 months of transplantation. This study has focused to evaluate the spectrum of infectious complications in post renal recipients in first 6 months of follow up and evaluate the most common type of infection. 


\section{International Journal of Current Science Research and Review}

ISSN: 2581-8341

Volume 05 Issue 01 January 2022

DOI: 10.47191/ijesrr/V5-i1-21, Impact Factor: 5.825

IJCSRR@ 2022

WWW.ijcsrr.org

\section{MATERIALS AND METHODS}

Inclusion criteria:

1. All patients undergoing renal transplantation from 2016 to 2018 .

2. All patients presenting in first 6 months with infectious complications.

\section{Exclusion criteria:}

1. Patient who develop infectious episodes after 6 months of transplant.

Study Design: Prospective study.

Method of data collection: Prospective hospital record analysis.

The study group comprised 75 cases of renal transplant recipients, who underwent renal transplantation for end stage renal failure (ESRF) at Department of Nephrology SKIMS.

It included :

○ $\quad 75$ cases of live related donar renal transplantation were followed from 2016 to 2018.

- All renal transplant recipients were screened pre operatively for the presence of any overt or occult infection by

\section{Post operative care}

Immunosuppressive protocol consisted of administration of Triple drug regime - Tacrolimus, Mycophenolate mofetil and Prednisolone. Rejection episodes were treated with Intravenous Methylprednisolone, Intravenous Dexamethasone or Oral Prednisolone or OKT3. Whenever infections occurred, samples were collected accordingly. Patients were immunized against Hepatitis B whenever possible.

\section{Methodology}

A. Collection of specimen.

B. Microscopical examination.

C. Culture procedure and identification of organisms.

\section{Collection of specimens}

Urine, Drain fluid, foley catheter tip and Drain tip were collected from all cases. According to signs and symptoms, Blood, Serum, Sputum, Oral scrapings, Faeces, Pus and CSF were collected.

\section{OBSERVATION AND RESULTS}

Infection in renal transplantation is a major and severe penalty of immunosuppression and is associated with high mortality. In order to prevent the occurrence of infection, one should know the commonest types of infection in that particular group of patients. Hence, a detailed account of post renal transplant infections was made to find out the present trend of infections and their incidence in renal transplant patients. All the details produced were based on the post renal transplant follow up of the patients which mainly explains the prevalence of infection, most common type of infection and most common organism involved.

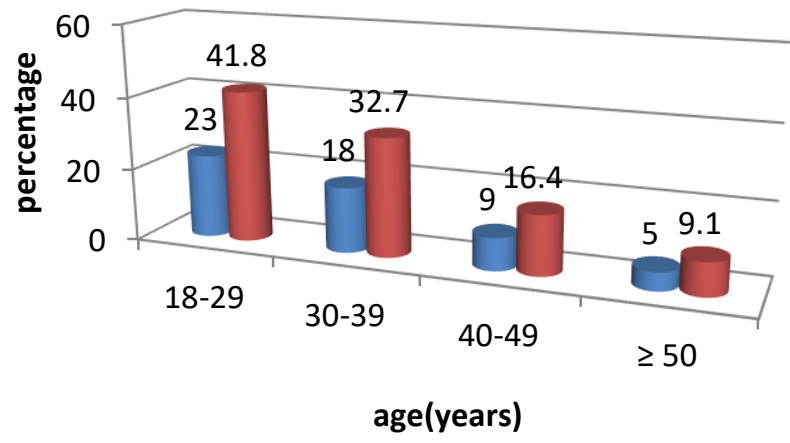

Figure- 1: Age distribution of study patients. 


\section{International Journal of Current Science Research and Review}

ISSN: 2581-8341

Volume 05 Issue 01 January 2022

DOI: 10.47191/ijesrr/V5-i1-21, Impact Factor: 5.825

IJCSRR @ 2022

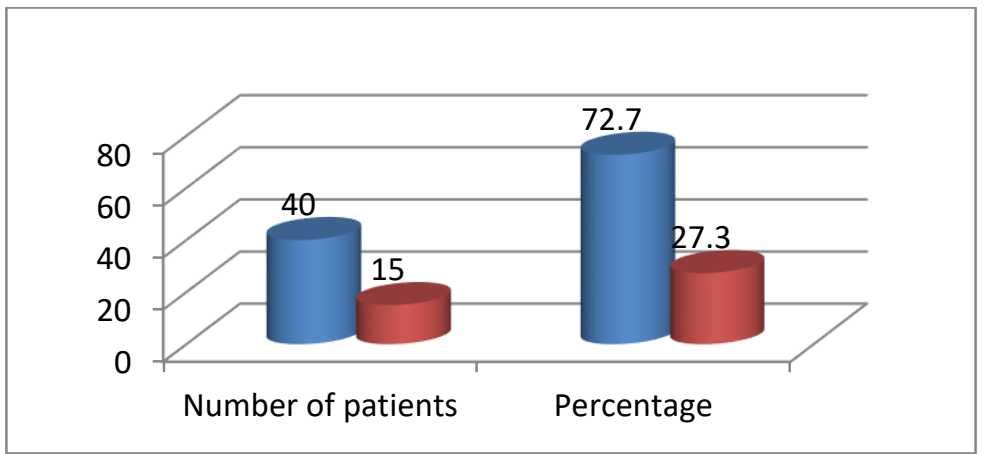

Figure- 2: Gender distribution of study patients

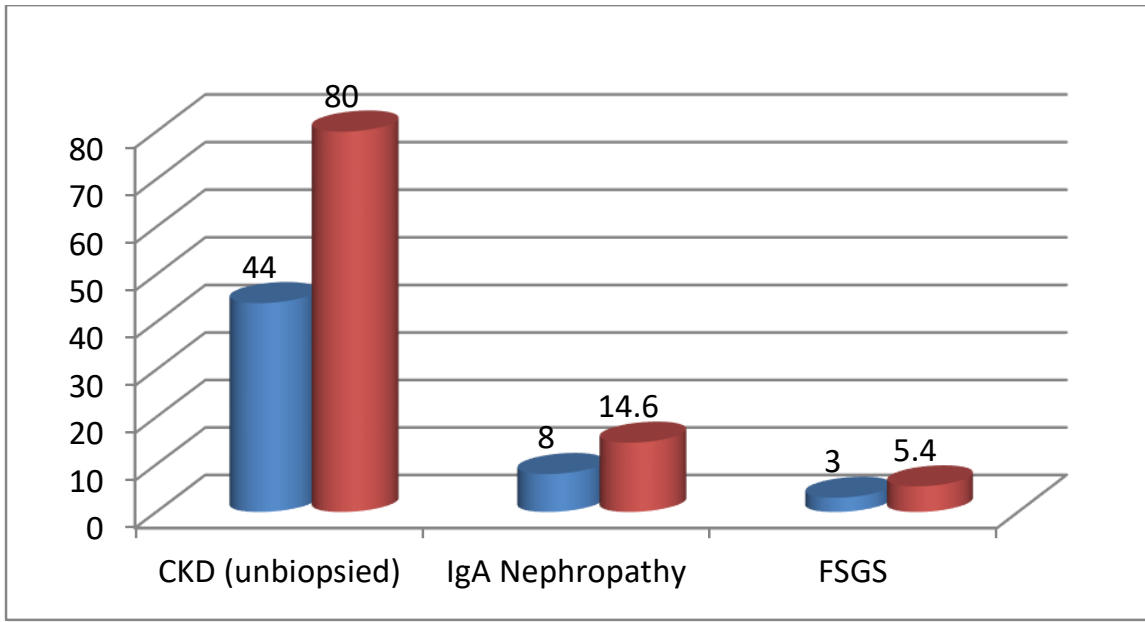

Figure-3: Basic disease in study patients.

Table 4: Blood and urine culture in study patients.

\begin{tabular}{|l|l|l|l|}
\hline \multicolumn{2}{|l|}{ Culture } & Number of patients & Percentage \\
\hline \multirow{2}{*}{ Blood Culture (total no. 38) } & Positive & 2 & 5.2 \\
\cline { 2 - 4 } & Negative & 36 & 94.8 \\
\hline \multirow{2}{*}{ Urine Culture (total no. 30) } & Positive & 17 & 56.7 \\
\cline { 2 - 4 } & Negative & 13 & 43.3 \\
\hline
\end{tabular}

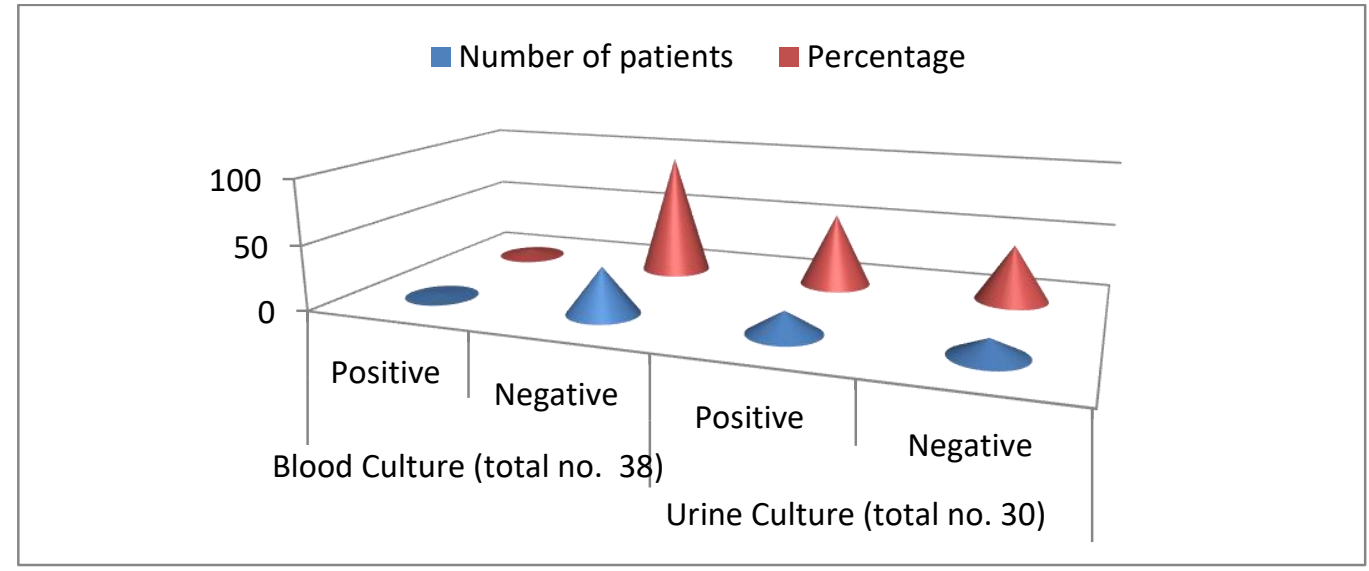

Figure- 4: Blood and urine culture in study patients 


\section{International Journal of Current Science Research and Review}

ISSN: 2581-8341

Volume 05 Issue 01 January 2022

DOI: 10.47191/ijesrr/V5-i1-21, Impact Factor: 5.825

IJCSRR@ 2022

WwW.ijcsrr.org

Table-5: Sputum culture, stool examination, CSF and PCR in study patients.

\begin{tabular}{|l|l|l|l|}
\hline \multicolumn{2}{|c|}{} & Number of patients & Percentage \\
\hline \multirow{4}{*}{ Sputum Culture (total no. 8) } & Sterile & 5 & 75 \\
\cline { 2 - 4 } & Klebsiella Pneumonie (K.P) & 1 & 12.5 \\
\cline { 2 - 4 } & Pneumocystis carnii (P.C) & 1 & 12.5 \\
\hline $\begin{array}{l}\text { Stool Examination } \\
\text { (total no. 7) }\end{array}$ & Cyst of Cryptosporidium (Cs) & 3 & 42.9 \\
\cline { 2 - 4 } $\begin{array}{l}\text { CSF Examination } \\
\text { (total no. 2) }\end{array}$ & No cyst or Ova detected (ncod) & 4 & 57.1 \\
\cline { 2 - 4 } & Positive for Cryptococal antigen (C.A) & 2 & 100 \\
\hline \multirow{2}{*}{ Negative for Cryptococal antigen (Cr.A) } & 0 & 0 \\
\hline
\end{tabular}

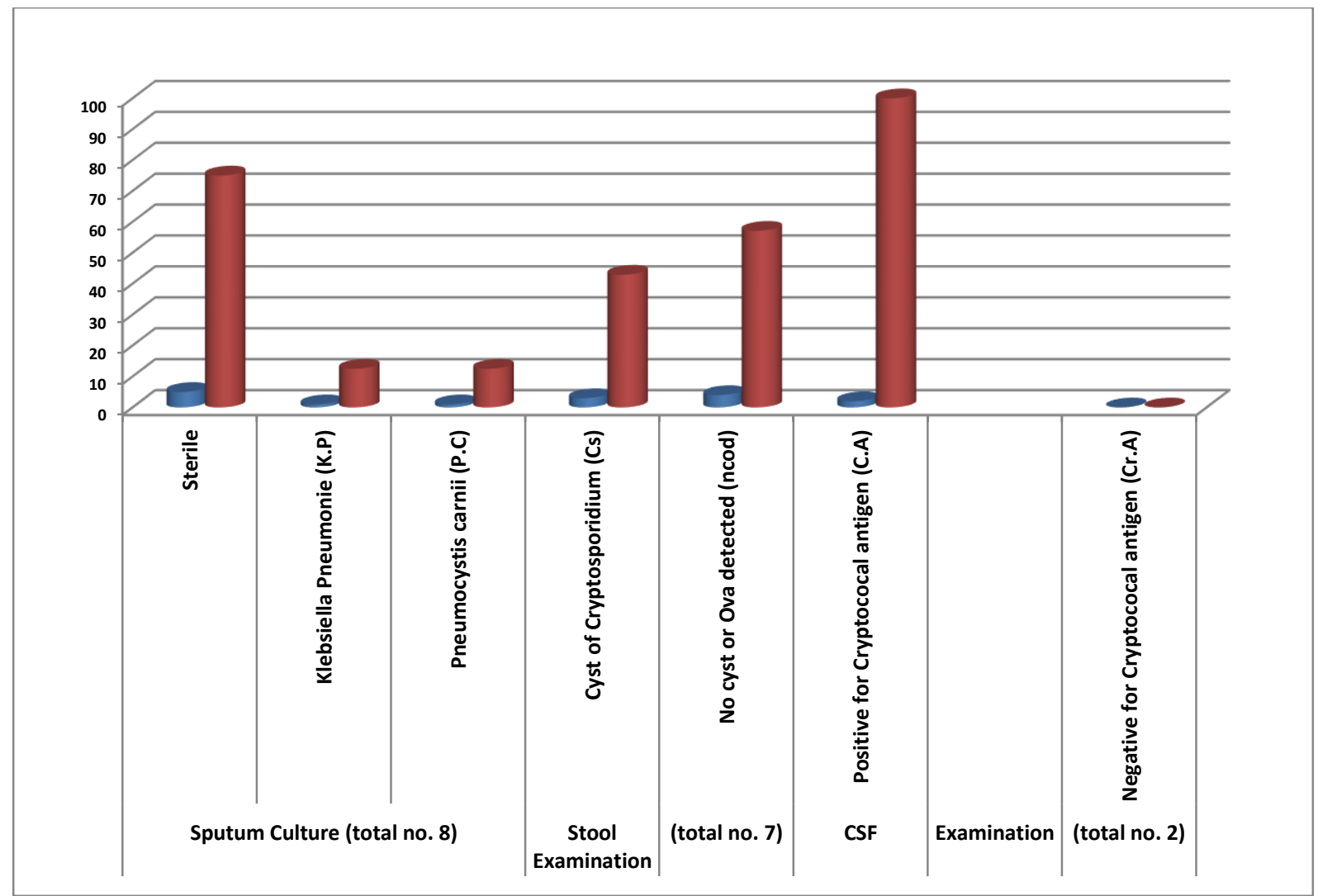

Figure- 5: Sputum culture, stool examination, CSF and PCR in study patients.

Table 6: PCR of study patients

\begin{tabular}{|l|l|l|}
\hline & $\begin{array}{l}\text { Number of } \\
\text { patients }\end{array}$ & percentage \\
\hline Herpes simplex positive (H.S.P) & 1 & 33.3 \\
\hline BK virus & 1 & 33.3 \\
\hline CMV virus & 1 & 33.3 \\
\hline
\end{tabular}


International Journal of Current Science Research and Review

ISSN: 2581-8341

Volume 05 Issue 01 January 2022

DOI: 10.47191/ijesrr/V5-i1-21, Impact Factor: 5.825

IJCSRR@ 2022

www.ijcsrr.org

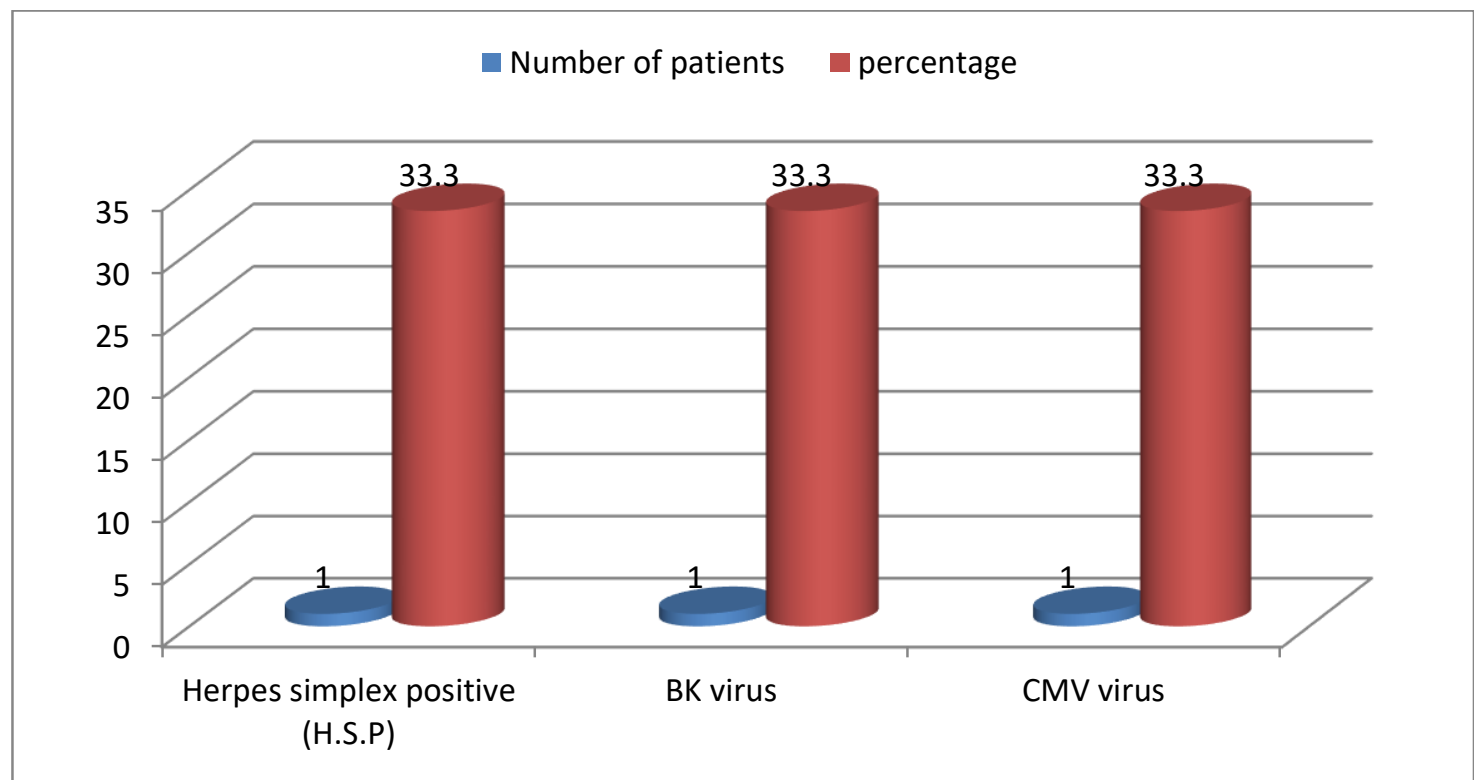

Figure 6: PCR of study patients (total no. 3)

Table 7: Repeat urine culture in study patients

\begin{tabular}{|l|l|l|}
\hline Urine culture & Number of frequency & Percentage \\
\hline Positive & 1 & 5.9 \\
\hline Negative & 16 & 94.1 \\
\hline
\end{tabular}

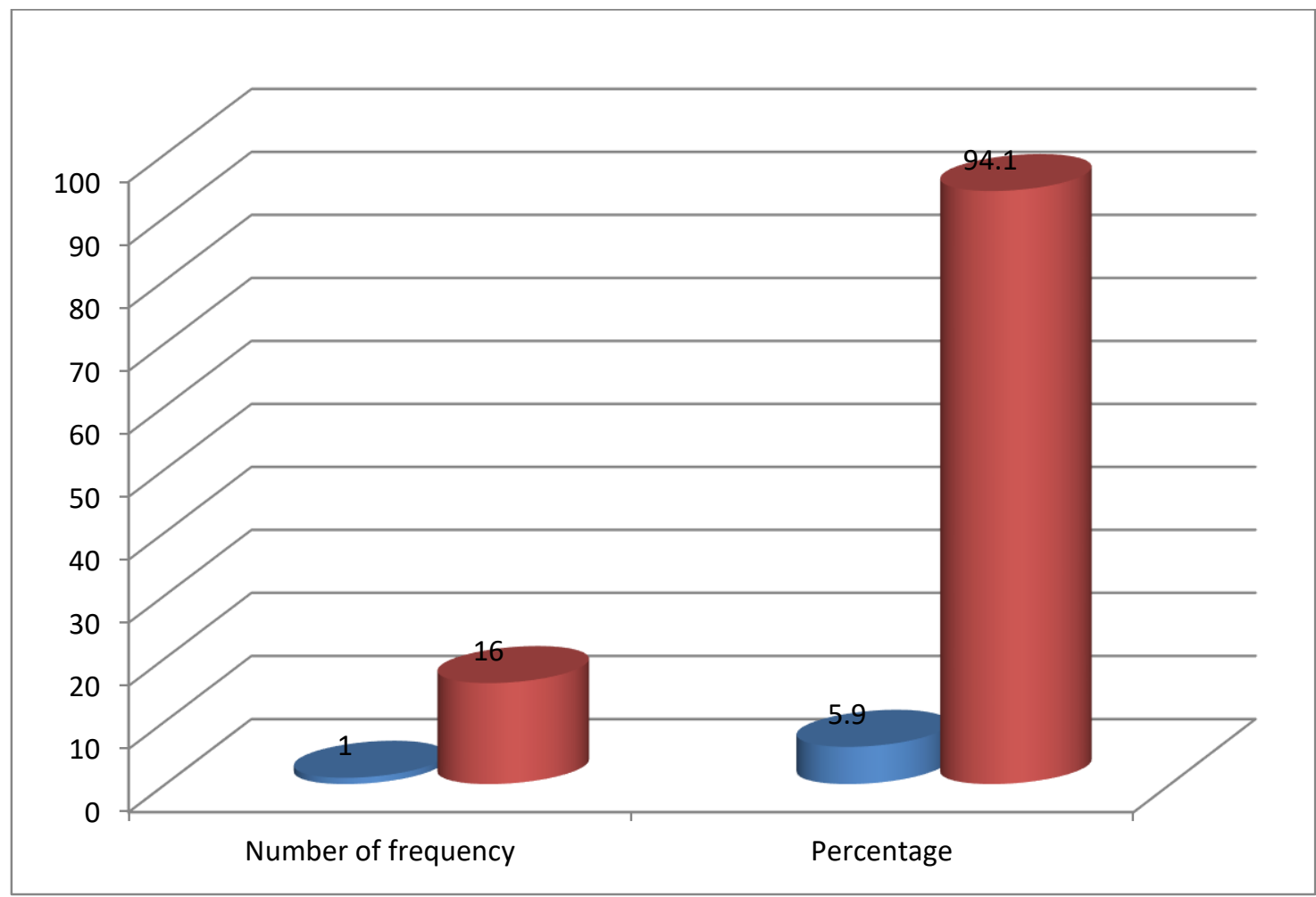

Figure-7: Repeated urine culture in study patients 
International Journal of Current Science Research and Review

ISSN: 2581-8341

Volume 05 Issue 01 January 2022

DOI: 10.47191/ijcsrr/V5-i1-21, Impact Factor: 5.825

IJCSRR@ 2022

www.ijcsrr.org

Table 8: Showing prevalence of infections in study patients

\begin{tabular}{|l|l|l|}
\hline Type of infections & Number of patients & Percentage \\
\hline UTI & 30 & 54.5 \\
\hline RTI & 8 & 14.5 \\
\hline GIT & 7 & 12.7 \\
\hline Skin and Soft tissue & 3 & 5.5 \\
\hline $\begin{array}{l}\text { Others (meningitis, septic } \\
\text { arthritis, cellulitis) }\end{array}$ & 7 & 12.7 \\
\hline Total & 55 & 100 \\
\hline
\end{tabular}

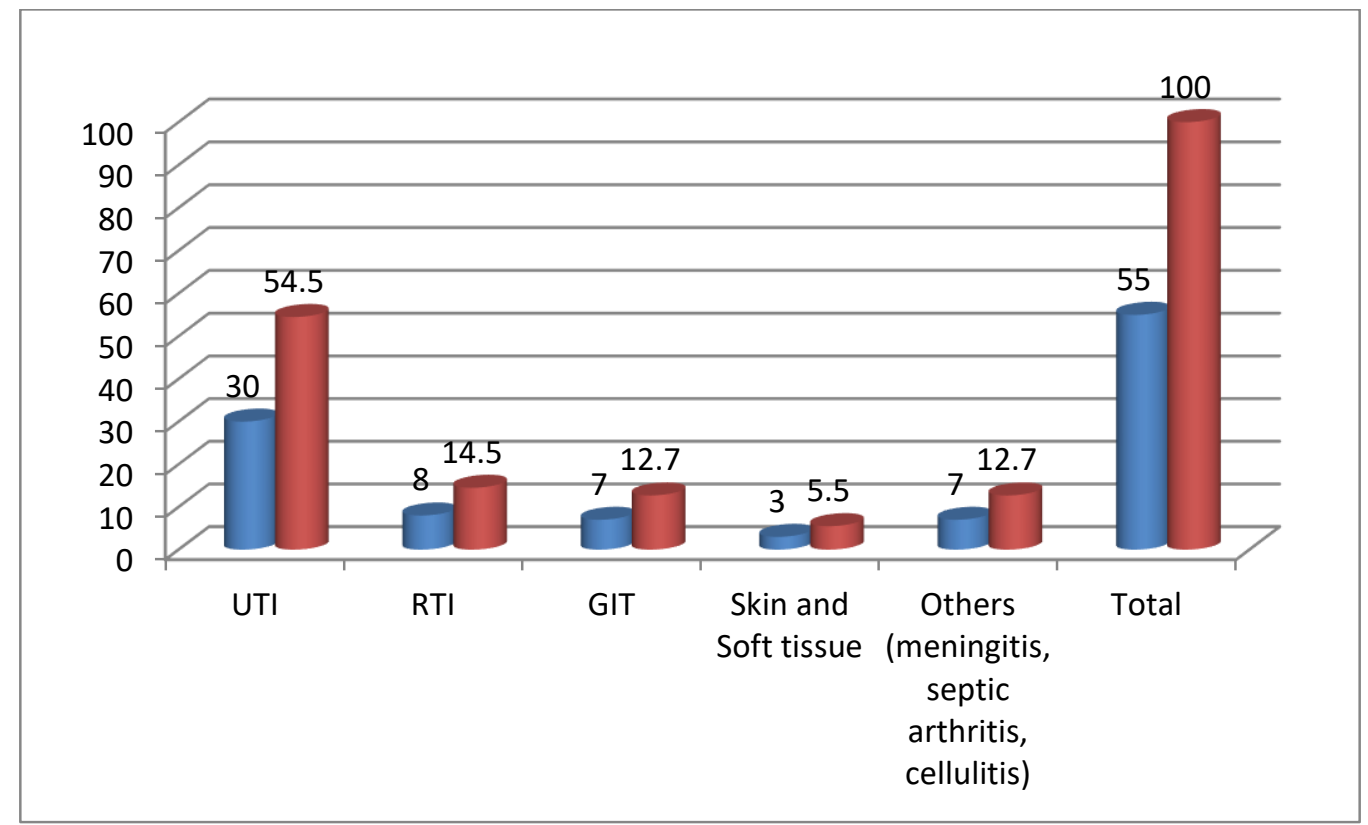

Figure-8: Showing prevalence of infections in study patients

Table 9: Showing nature of infections (culture positive) in study patients.

\begin{tabular}{|l|l|l|}
\hline Nature of infections & Number of patients & Percentage \\
\hline Bacterial & 20 & 36.4 \\
\hline Viral & 4 & 7.3 \\
\hline Fungal & 2 & 3.6 \\
\hline Protozoal & 3 & 5.5 \\
\hline
\end{tabular}


International Journal of Current Science Research and Review

ISSN: 2581-8341

Volume 05 Issue 01 January 2022

DOI: 10.47191/ijcsrr/V5-i1-21, Impact Factor: 5.825

IJCSRR@ 2022

www.ijcsrr.org

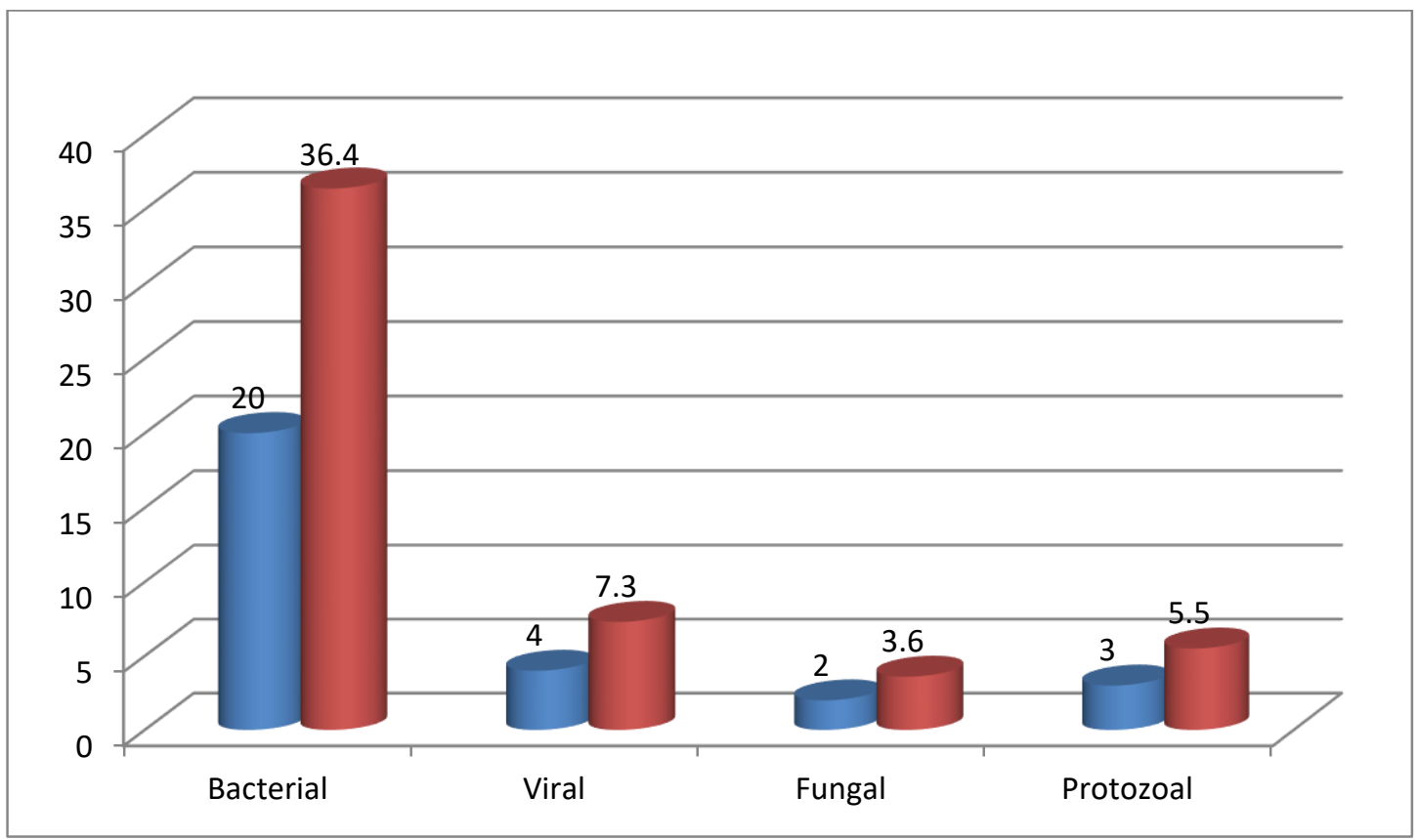

Figure-9: Showing nature of infections (culture positive) in study patients

Table 10: Organism involved in study patients

\begin{tabular}{|l|l|l|}
\hline Organism Involved & $<$ Month & $\mathbf{1 - 6}$ Months \\
\hline E. coli & 0 & 8 \\
\hline Kliebsiella & 0 & 7 \\
\hline Pseudomonos & 0 & 5 \\
\hline Sttaphyloccuos aureus & 0 & 2 \\
\hline CONS & 0 & 1 \\
\hline Acinetobacter Boumani & 0 & 1 \\
\hline CMV & 1 & 0 \\
\hline BK Virus & 1 & 0 \\
\hline Herpes Virus & 1 & 1 \\
\hline Candida albacans & 0 & 1 \\
\hline Cryptosporidium parvum & 0 & 3 \\
\hline
\end{tabular}




\section{International Journal of Current Science Research and Review}

ISSN: 2581-8341

Volume 05 Issue 01 January 2022

DOI: 10.47191/ijcsrr/V5-i1-21, Impact Factor: 5.825

IJCSRR @ 2022

WWW.ijcsrr.org

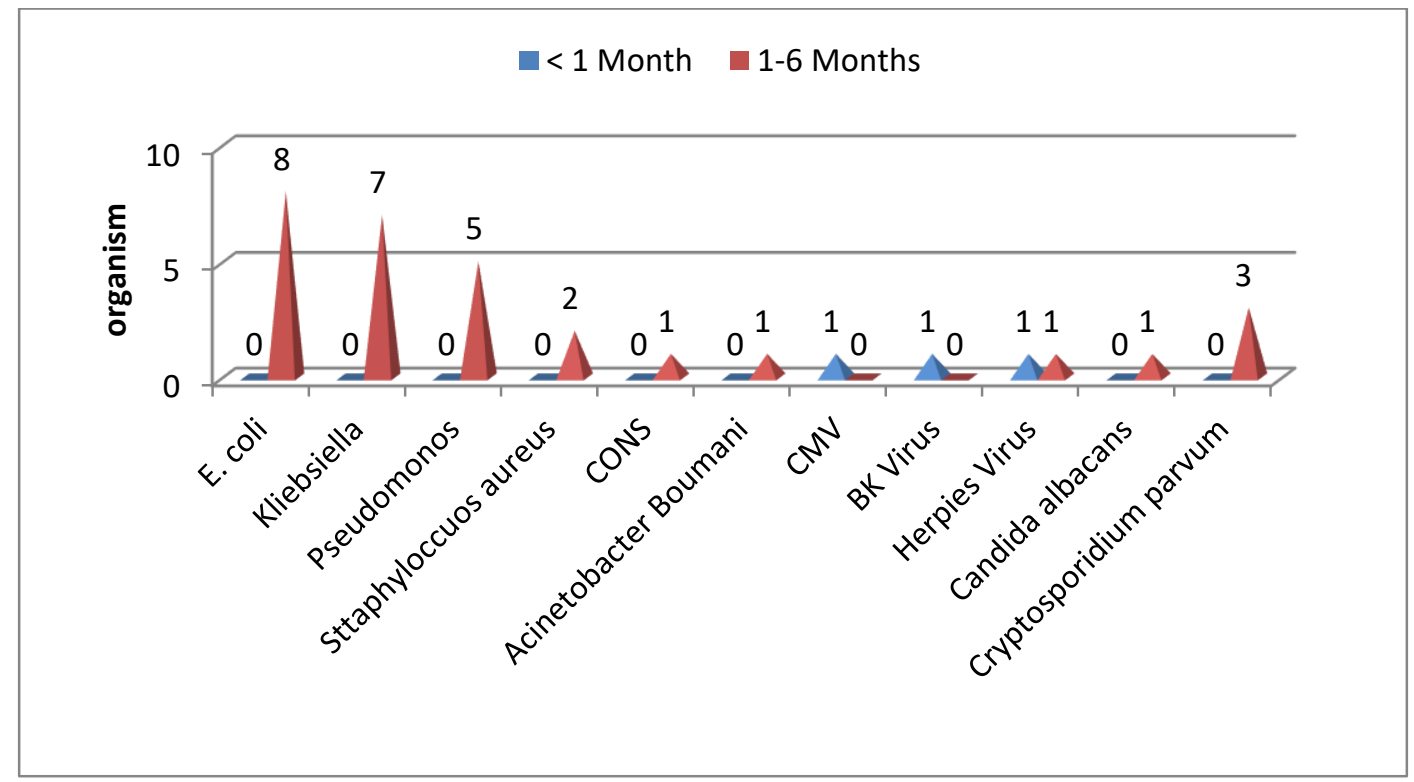

Figure-10: Organism involved in study patients

\section{DISCUSSION}

The current study group comprised of 53 male recipients and 22 of female recipients, male to female ratio being $2.4: 1$. However, Ravikumar (1992), ${ }^{140}$ has reported predominance of male population $(82.5 \%)$ and male to female ratio of $4.7: 1$. Ram, R. et al., (2005) reported that out of 169 renal transplant patients $136(80.4 \%)$ patients were males and $33(19.5 \%)$ were females in this population. Kumar et al., (2016) revealed the study population renal transplant patients $(\mathrm{n}=45,35$ male and 10 female) had a mean age of $35.5 \pm 10.4$ years and follow-up after transplant was $2.1 \pm 1.7$ years. The predominant age group in this study was between 18 - 29 years (Table-1).

All 75 cases underwent live related donor transplantation and no case underwent Cadaver transplantation. Urinary tract infections were commonest followed by respiratory tract infections (Table-8). Bacterial infections were the most common infections in the post transplant period (Table-9).

\section{URINARY TRACT INFECTION}

Urinary tract infections (UTIs) are the most common bacterial infections requiring hospitalization in kidney transplant recipients, followed by pneumonia, postoperative infections, and septicemia. Women are at greatest risk for UTIs; other risk factors include deceased-donor transplant, kidney-pancreas transplantation with bladder drainage, prolonged catheterization, uretero-vesical stents, and increased immunosuppressed state (Lorenz EC and Cosio FG., 2010). ${ }^{155}$ Urinary tract infections were the single most common infection occurring in renal transplant recipients, as noted in the present study and also reported by Rubin, et al., (1981) ${ }^{141}$ and Jadav, et al., (1992). ${ }^{142}$ Urinary tract infection constituted 54.5\% (Table-8) of the total infections in this study. Umesh et al., (2007) has reported $31.1 \%$ of UTI incidence in transplant recipient. Jadav, et al., (1992) observed the incidence of 53\% which were in congruence with the present study. Krieger JN, et al. [1977] observed 61\%, the reports of Leigh, D.A. (1970) and Chan, P.C. (1990) varies from 30-79\%, 31\% incidences based on study by Chan PC, et al. [1990]. The incidences of 51\% reported by Ravi kumar (1998) were in proximity with current investigation. A study of 28,942 primary renal transplant recipients from the U.S. has revealed a cumulative UTI incidence of $17 \%$ during the first 6 months after transplantation; at 3 years the incidence were $60 \%$ for women and $47 \%$ for men (Abbott KC. et al., 2004). Kumar, A. et al., (2016) reported UTI as most common infection, out of 45 patients 15 cases were of UTI. UTI occurred in transplant recipient was found as $72.7 \%$ Sujit et al., (2016) .

Most of the infectious occur during early months of transplantation and the most common organism are $E$. coli and Klesiella. The aetiological agents causing urinary tract infection in the present study were Bacteria and Fungi. The bacterial isolates included E. coli, Klebsiella pneumoniae, Klebsiella oxytoca, Pseudomonas aeruginosa, Staph aureus, Acinetobacter baumanii and 


\section{International Journal of Current Science Research and Review}

ISSN: 2581-8341

Volume 05 Issue 01 January 2022

DOI: 10.47191/ijcsrr/V5-i1-21, Impact Factor: 5.825

IJCSRR @ 2022

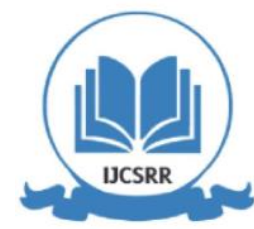

WWW.ijesrr.org

Enterococcus faecalis. Similar organisms were also isolated by Paul, D. Ellner (1987). E. coli followed by Klebsiella pneumonia were the most frequently isolated organism in this study. Takai et al., (1998) found that E.coli was the commonest organism causing urinary tract infection. Gram negative bacilli of Enterobacteriaceae family were most frequently isolated in urinary tract infections in a study by Morz, E. et al., (1993). 3.3\% of the urinary tract infections were due to fungi of which all were caused by Candida albicans. Funguria has been attributed in part to the widespread use of broad spectrum antibiotics, Corticosteroid, antineoplastic agents, immunosuppressive agents and urinary catheterization. Fluconazole is the drug of choice for susceptible Candida species; other azoles and echinocandins are not concentrated in the urinary tract and thus are less likely to be effective if infection is confined to the urinary tract (Pappas PG. et al., 2004; 2009).

\section{RESPIRATORY TRACT INFECTION}

Respiratory tract infection occurred in $16.3 \%$ of the transplant recipient in comparison with $33 \%$ based on the study by the Jha R, et al. [1999].

Respiratory tract infection constituted about $14.5 \%$ of the total infections which was second most prevalent infection in the current study (Table-8). These reported incidence showed proximity with some of the previous studies whereas some reports showed a significant variation: $8 \%$ of incidences were observed by Moore, F.D et al., (1983), 15\% by Giri (1992) which is approximately same as reported by present study, $12.6 \%$ by Ravi kumar (1998), 33\% by Jha R, et al. [1999]. Maraha, B. et al., (2001) reported $8 \%$ of RTI incidences as second most prevalent infection in renal transplant patients following UTI. Organisms causing bacterial infection were E. coli, Gee-Chen Chang (2004), mention which organism was involved in current study.

\section{GASTROINTESTINAL TRACT INFECTION}

Infections of the Gastrointestinal tract occurred in $12.7 \%$ of the total infectious patients (Table- 8 ), which were not in view with previous Incidence. Giri, (1992) reported 5\% incidences and 17.2\% of were reported by Attoparmark, M R. et al., (2002) and the most common organism was Candida. The causative organisms isolated was Cryptosporidium. Majority of the GIT infections occurred between 3-6 months post transplant duration.

\section{SKIN AND SOFT TISSUE INFECTION}

Skin and soft tissue infection accounted for $5.5 \%$ of the infections (Table-10). Among the infections Staph aureus-1 Herpies-2 and Histoplasma-1.

\section{CYTOMEGALO VIRAL INFECTION}

Cytomegalovirus infection is a recognized problem of the early post transplant period in renal transplant recipients (Boehter A., 1994). In the present study, one patients (1.8\%) developed cytomegalovirus infection which was detected in the first month of transplant (Table ). Kumar, A. et al (2016) reported cytomegalovirus infected six out of forty-five patients and Maraha, B. et al., (2001) reported $8 \%$ of cytomegalovirus infections.

\section{CENTRAL NERVOUS SYSTEM INFECTION}

Two patients were observed to develop meningitis which constituted 3.6\% of the total infectious. Giri, (1992) has reported the incidence of $0.7 \%$ in his study. The causative organism was found to be Cryptococcus neoformans. Both patients developed meningitis in the 6th month post transplant. Ravi kumar (1998) has also repoted two cases of Cryptococcus neoformans meningitis in his study. It has been mentioned that Cryptococcus neoformans, the single most common cause of central nervous system infection in the renal transplant patients, occurs almost exclusively in the late post transplant period (more than six months after transplant ) Robert H. Rubin, (1993).

In the present study it was noted that infections in renal transplant patients were commonly caused by Bacteria (36.4\%) followed by Viruses (7.3\%), Fungi(3.6\%) and Protozoal (5.5\%). However, Alangaden et al., (2006) has reported viral infections (17\%), pneumonia (8\%), and surgical wound infections (7\%), Enterococcus spp. (33\%) and Escherichia coli (21\%) were the most prevalent uropathogens. Wang X. et al., (2014) studied Pulmonary infections after renal transplantation. Infections more likely to occur within 6 months after transplantation, and the peak being at about 3 months. Mixed infections (62.1\%) were the common 


\section{International Journal of Current Science Research and Review}

ISSN: 2581-8341

Volume 05 Issue 01 January 2022

DOI: 10.47191/ijcsrr/V5-i1-21, Impact Factor: 5.825

IJCSRR @ 2022

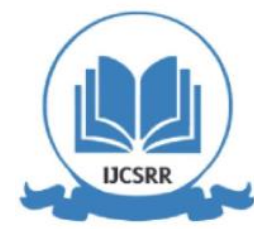

WWW.ijesrr.org

types, followed by virus infection $(24.1 \%)$ and bacterial infection $(13.8 \%)$. In 10 patients taken chest radiographs with pulmonary infections after renal transplantation, patchy shadow and/or increased lung markings were showed in 7 cases $(70 \%)$. ${ }^{166}$

\section{CONCLUSION}

Infections are the major bane of renal transplants, and the leading cause of hospatilization and also leads to considerable morbidity and mortality. The predominant age group undergoing renal transplantation was between 18 - 29 yrs. The male prevalence more, Urinary tract infections were the highest and commonest infection observed. The microorganisms involved in the infections were Bacteria (36.4\%), Fungi (3.7\%), Viruses (7.6\%) and Parasites (5.5\%). In Urinary tract infection, E. coli ollowed by Klebsiella pneumoniae were the predominant bacterial isolates. Candida albicans were the commonest fungus isolated. Among the Gastrointestinal tract infections, Cryptosporodium was the commonest Protozoal isolate. Cryptococcus neoformans was isolated in two cases of meningitis. It is clearly emphasized that early and correct recognition of infectious agents in renal transplant recipients during immediate transplant period will improve the outcome of the patients. In this study the organisms causing infection during the immediate operative period has been categorized, which will give the treating physician a reasonable idea to suspect the system and cause of infection during the particular post renal transplant period.

\section{ACKNOWLEDGEMENTS}

We are very thankful to the Department of KIDNEY TRANSPLANT UNIT SKIMS to allow us to carry out the investigation.

\section{REFERENCES}

1. Abbott KC, Swanson SJ, Richter ER, Bohen EM, Agodoa LY, Peters TG, Barbour G, Lipnick R, Cruess DF: Late urinary tract infection after renal transplantation in the United States. Am J Kidney Dis 44: 353-362, 2004.

2. Abbott, K.C., Swanson, S.J., Richter, E.R., Bohen, E.M., Agodoa, L.Y., Peters, T.G., Barbour, G., Lipnick, R. and Cruess, D.F., 2004. Late urinary tract infection after renal transplantation in the United States. American journal of kidney diseases, 44(2), pp.353-362.

3. Alangaden GJ, Thyagarajan R, Gruber SA. Infectious complications after kidney transplantation: current epidemiology and associated risk factors. Clin Transplant 2006; 20(4): 401-9.

4. Arend SM, Mallat MJ, Westendorp RJ, van der Woude FJ, van Es LA. Patient survival after renal transplantation; more than 25 years follow-up. Nephrol Dial Transplant 1997;12:1672-9.

5. Attoparmark MR. Systemic Fungal infections after renal transplantation. Scand J Infect. Dig., 2002; 34(4): $284-8$.

6. Attoparmark MR. Systemic Fungal infections after renal transplantation. Scand J Infect. Dig., 2002; 34(4): 284-8.

7. Chan PC, Cheng IK, Wong KK, Li MK, Chan MK. Urinary tract infections in post renal transplant patients. Int Urol Nephrol. 1990;22(4):389-96.

8. Chan PC, et al. Urinary tract infections in post renal transplant. Int. Urol. Nephrol., 1990; 22(4): 389-96.

9. Desai J D, S.Jadav, Morbidity and Mortality due to infection in Renal allograft recipients. Indian. J. Nephrology.2:4548,1992 .

10. Dharnidharka VR, Agodoa LY, Abbott KC. Risk factors for hospitalization for bacterial or viral infection in renal transplant recipients--an analysis of USRDS data. Am J Transplant. 2007;7:653-61.

11. Dr. Ravikumar Dissertation on infections in renal transplant recipients. Department of Microbiology, Government General Hospital, Chennai(1998).

12. Dr. Ravikumar Dissertation on infections in renal transplant recipients. Department of Microbiology, Government General Hospital, Chennai(1998).

13. Fishman JA. Pnuemocystis carinii and parasitic infections in transplantation. Infect Dis Clin North Am. 1995:9;1005-44 6.

14. Fox BC, Sollinger HW, Belzer FO, Maki DG: A prospective, randomized, double- blind study of trimethoprimsulfamethoxazole for prophylaxis of infection in renal transplantation: Clinical efficacy, absorption of trimethoprimsulfamethoxazole, effects on the microflora, and the cost-benefit of prophylaxis. Am J Med 89: 255-274, 1990

15. Gee-Chen Chang, MD; Chieh-Liang Wu, MD; Shin-Hung Pan, MD; Tsung-Ying Yang, MD; Chung-Shih Chin, MD; YunChiu Yang, MD and Chi-Der Chiang, MD. The Diagnosis of Pneumonia in Renal Transplant Recipients Using Invasive and Noninvasive Procedures. Chest. 2004;125: p541-547. 
ISSN: 2581-8341

Volume 05 Issue 01 January 2022

DOI: 10.47191/ijesrr/V5-i1-21, Impact Factor: 5.825

16. Hadley S, Karchmer AW. Fungal infections in solid organ transplant recipients. Infect Dis Clin North Am. 1995:9;104574. 7.

17. Hinmanf, Schmaelzle, Belzer. Urinary tract Infection and Renal Homotransplantation Bacterial invasion. J. Urol.101:673679,1969 .

18. Jha R, et al. Pulmonary Infection after Kidney Transplantation. J Association Physicians India, 1999; 47(8): 779-83.

19. KDIGO clinical practice guideline for the care of kidney transplant recipients. Am J Transplant 9: S1-S155, 2009.

20. Ko, K. S., Cho, D. O., Ahn, J. H., Lee, T. W., Ihm, C. G., Chang, S. G., ... \& Joo, H. Z. (1994, August). Infections after renal transplantation. In Transplantation proceedings (Vol. 26, No. 4, pp. 2072-2074.

21. Krieger JN, et al. UTI in Kidney transplantation. Urology, 1977; 9(2): 130-6.

22. Kumar, A., Agarwal, C., Hooda, A.K., Ojha, A., Dhillon, M. and Kumar, K.H. Profile of infections in renal transplant recipients from India. Journal of family medicine and primary care, 2016. 5(3), p.611.

23. Leigh.DA. The outcome of Urinary tract infection in patients after human cadaver Renal transplantation. Br. J. urology, 101:453-456,1970.

24. Lorenz EC, Cosio FG: The impact of urinary tract infections in renal transplant recipients. Kidney Int 78: 719-721, 2010.

25. Maraha B, Bonten H, van Hooff H, Fiolet H, Buiting AG, Stobberingh EE. Infectious complications and antibiotic use in renal transplant recipients during a 1 year followup. Clin Microbiol Infect 2001;7(11):619-25.

26. Maraha B, Bonten H, Van Hooff H, Fiolet H, Buiting AG, Stobberingh EE. Infectious complications and antibiotic use in renal transplant recipients during a 1-year follow-up. Clinical microbiology and infection. 2001 Nov;7(11):619-25.

27. MooreF.D, kohler, Strsm, Tilney N.L.The Deeling Mortality from Pneumonias in renal transplant patients. Infect. sursery, 2:13:1983.

28. Mroz E, Lizar J, Szepietowski T, Satarek J, Bartelmus J. Urinary tract infections in the first three months following kidney transplantation. Polski Tygodmik Lekarshi. 48(20-22):448-51,1993.

29. Pappas PG, Rex JH, Sobel JD, Filler SG, DismukesWE,Walsh TJ, Edwards JE; Infectious Diseases Society of America: Guidelines for treatment of candidiasis. Clin Infect Dis 38: 161-189, 2004.

30. Pappas PG, Silveira FP; AST Infectious Diseases Community of Practice: Candida in solid organ transplant recipients. Am J Transplant 9[Suppl 4]: S173-S179, 2009.

31. Paul D.Ellner: Diagnostic procedures in infectious Disease. MCNA. Nov.1987. Update on antibiotics. 1065-1073.

32. Pava CV. Fungal infections in solid organ transplantation. Clin Infect Dis 1993:16:677-88.

33. Ram R, Dakshina Murty KV, Prasad N. Time table of infections after renal transplantation - South Indian experience. Indian J Nephrol 2005;15 Suppl 2:S14-21.

34. Richard Webb, W Gordongamsu. Pulmonary complications of renal transplantation. A survey of patients treated with low dose immunosuppression. Radiology 126:1-8, Jan 1978.

35. Rubin RH:Infection in the organ transplant recipient. Am. J Med 70: p405-411,1981.

36. Snyder, J. J., Israni, A. K., Peng, Y., Zhang, L., Simon, T. A., \& Kasiske, B. L. (2009). Rates of first infection following kidney transplant in the United States. Kidney international, 75(3), 317-326.

37. Takai K, Tollemar J, Wilczek HE, Groth CG, Urinary tract infections following renal transplantation. Clin Transplant. $1998 \mathrm{Feb} ; 12(1): 19-23$.

38. Umesh, L., Mahesh, E., Kumar, A., Punith, K., Lalitha, K. and Suman, G., 2007. Infections in renal transplant recipients. Journal, Indian Academy of Clinical Medicine, 8(4), pp.316-323.

39. vanDenberg AP, Klomparker IJ, Haagsma EB et al. Evidence for an increased rate of bacterial infections in liver transplant patients with cytomegalovirus infection. Clin Transplant. 1996:10:224-31. 8.

40. Wang X, Wang Y, Zhu Q, Guo G, Yuan H. Pulmonary infection in the renal transplant recipients: Analysis of the radiologic manifestations. Radiology of Infectious Diseases. 2014 Dec 1;1(1):3-6.

Cite this Article: Dr. Mohd Ashraf Bhat, Dr. Jawher Ul Islam, Dr. Wani Firdous Dawood, Dr. Peerzada Khibrat, Dr. Aamir Shafi (2022). Post Renal Transplant Infections: A Six Month Follow-Up Study from a Kidney Transplant Institute of North India. International Journal of Current Science Research and Review, 5(1), 178-188 